\title{
FREQUENCY OF TRANSITIONAL CELL CARCINOMA IN LOCAL SUBURBAN POPULATION OF KARACHI
}

\author{
Syed Mehmood Hasan, Fauzia Imtiaz and Syed Muhammad Hasan
}

\begin{abstract}
To determine the clinicopathological characteristics and frequency of different pathological lesions, particularly Transitional Cell Carcinoma in urinary bladder biopsies, this study was conducted in histopathology section of tertiary care hospitals (Jinnah and Civil hospital) filtering the suburban population of Karachi during August 2001 to July 2005. All patients who visited the Urology Out Patient Department and presented with haematuria, dysuria etc. were included. Cystoscopy and bladder biopsies were performed. The biopsies were preserved in $10 \%$ formalin. Gross examination was done and embedded in paraffin. Light microscopy technique was used for diagnosis. Out of 43 patients, 31 (72.09\%) were males and 12 (27.90\%) were females. The spectrum of pathological lesions included inflammations, dysplasia and tumours. Transitional cell carcinoma was the most common tumour seen in this study; (93.33\%) cases. The peak age of incidence was between 41-68 years.
\end{abstract}

KEY WORDS: Transitional Cell Carcinoma. Malignancy. Urinary bladder biopsy.

\section{INTRODUCTION}

Transitional Cell Carcinoma (TCC) is a well-known tumour of the urinary bladder, yet its incidence in the ureters is rare, accounting for only $1 \%$ of all urinary tract neoplasms ${ }^{1}$. Epidemiologically transitional cell carcinoma of the bladder represents $90-95 \%$ of cases in Europe, while $5 \%$ represents mostly squamous cell carcinoma. TCC of the bladder poses a significant worldwide clinical problem, with an estimated 54,200 new cases and 12,100 associated deaths reported in the United States in 1999 alone $^{2}$. In more than $75 \%$ of patients, the most common sign is gross or microscopic haematuria, with the patient asymptomatic ${ }^{3}$. Thus, persistent dipstick-hematuria in the absence of symptoms must be investigated rigorously by excretory or retrograde urography. The relative frequency of histological subtype of bladder carcinoma depends on the clinical setting. About $90 \%$ of bladder carcinoma reported from the West is transitional cell type ${ }^{4}$. In large series reported from Egypt, squamous cell carcinoma (SCC) accounted for $59-73 \%$ of bilharzial bladder cases ${ }^{5}$. The incidence of the TCC in North America has been steadily rising during the past years with more than 50,000 new cases annually reported ${ }^{6}$. The male to female ratio for TCC is approximately $3: 1$, and about $80 \%$ of the patients are between $40-80$ years of age $^{6}$. A number of factors have been implicated in the causation of TCC. Some of the more important con- tributors include the cigarette smoking, industrial exposure to acrylamine schistosoma hematobium cyclophosphamide, artificial sweeteners and long-acting use of analgesics. How these influence to induce cancer is unclear, but a number of cytogenetic and molecular alterations are heterogeneous.

\section{MATERIAL AND METHODS}

This retrospective study was conducted in histopathology section of tertiary care hospitals (Jinnah and Civil Hospitals, Karachi), filtering the suburban population of Karachi over a period of four years from August 2001 to July 2005. The inclusion criteria of the study were all the patients who visited in the urology department OPD; underwent cystoscopy and bladder biopsies due to complaints of hematuria, dysuria, urgency and frequency etc. The biopsies were preserved in $10 \%$ formalin. Gross examination was done and embedded in paraffin. Histological sections of $5 \mu$ thickening were stained with Hematoxylin \& Eosin ( $H$ \& E), PAS, PAS-D. Light microscopy was carried out for diagnosis.

\section{RESULTS}

Different pathological lesions were observed in the biopsies received as listed in Table I. Tumours make up highest percentage (69\%) among these lesions followed by acute and chronic non-specific inflamma- 
tions (23.25\%) and dysplasia (6.97\%). Out of 43 patients, 31 (72.09\%) were males and 12 (27.90\%) were females. Age ranged from 24 to 78 years. As the tumours account for the highest percentage of the pathological lesions, their distribution shown in Table II. The TCC accounted for 93.33 percent of all tumours while the squamous cell carcinoma and adenocarcinoma were 3.33 percent respectively. Histological distribution is presented in Table III, reveals that the maximum number of cases were TCC-II (18), with the percentage of 64.28 followed by TCC-I and TCC-III with 17.85 and 10.72 percentages respectively (Figure I).

TABLE I:

FREQUENCY OF DIFFERENT PATHOLOGICAL LESIONS

\begin{tabular}{|c|c|c|}
\hline Lesion & Observed & Percentage \\
\hline Tumours & 30 & 69.76 \\
\hline Inflammations & 10 & 23.26 \\
\hline Dysplasia & 3 & 6.98 \\
\hline Total & 43 & 100 \\
\hline
\end{tabular}

TABLE II:

DISTRIBUTION OF DIFFERENT TUMOURS SEEN IN BLADDER BIOPSIES

\begin{tabular}{|l|c|c|}
\hline \multicolumn{1}{|c|}{ Tumour } & Observations & Percentage \\
\hline $\begin{array}{l}\text { Transitional Cell } \\
\text { Carcinoma }\end{array}$ & 28 & 93.33 \\
\hline $\begin{array}{l}\text { Squamous Cell } \\
\text { Carcinoma }\end{array}$ & 1 & 3.33 \\
\hline Adenocarcinoma & 1 & 3.33 \\
\hline \multicolumn{1}{|c|}{ Total } & 30 & 100 \\
\hline
\end{tabular}

TABLE III:

HISTOLOGICAL GRADES OF CASES OF TCC

\begin{tabular}{|l|c|c|}
\hline \multicolumn{1}{|c|}{ Tumour grade } & Observations & Percentage \\
\hline TCC I & 5 & 17.85 \\
\hline TCC II & 18 & 64.28 \\
\hline TCC III & 3 & 10.72 \\
\hline TCC IV & 2 & 7.15 \\
\hline Total & 28 & 100 \\
\hline
\end{tabular}

TCC $=$ Transitional cell carcinoma
FIGURE I:

\section{PHOTOMICROGRAPH OF TRANSITIONAL CELL CARCINOMA GRADE I AT HIGH POWER}

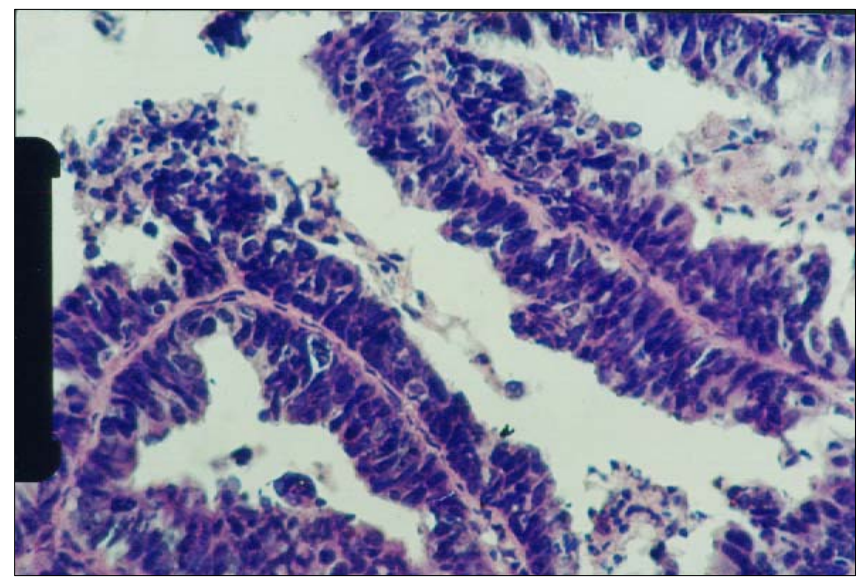

\section{DISCUSSION}

Transitional Cell Carcinoma is a well-known tumour of the urinary bladder, yet its incidence in the ureters is rare, accounting for only $1 \%$ of all urinary tract neoplasms ${ }^{1}$. Epidemiologically TCC of the bladder represents $90-95 \%$ of cases in Europe, while 5\% represents mostly squamous cell carcinoma. Patients included in this multi-centric, retrospective study were mostly representing urban population of Karachi. Tumours made highest percentage (69\%) among these lesions followed by acute and chronic non-specific inflammations (23.25\%) and dysplasia (6.97\%). The TCC accounted 93.33 percent of all tumours while the squamous cell carcinoma and adenocarcinoma were 3.33 percent respectively. In Sri Lanka, TCC accounted for $93.4 \%$ of primary bladder cancer there was a male predominance with sex ratio of $6: 1^{9}$. In Arabs, $83 \%$ of patients presented with superficial TCCB and $17 \%$ diagnosed with invasive disease with male to female ratio 13.4:1, and the mean age at presentation was 64 years $^{10}$. Ca UB occurs more in male with a male female ratio of 4.5:1 and a high incidence after 40 years of age ${ }^{11}$. Inflammatory lesions were common in younger group especially females and the tumour was seen in slightly older age group predominantly men ${ }^{12}$. Histological distribution reveals that the maximum number of cases $(64.28 \%)$ observed TCC-II, followed by TCC-I and TCC-III with the 17.85 and 10.72 percentages respectively. As compared to local observations, $44 \%$ cases were found to be Grade II, and $29.5 \%$ Grade III ${ }^{13}$. Inflammatory lesions were found to be $23.26 \%$ and dysplasia was $6.98 \%{ }^{14}$.

\section{CONCLUSION}

Our study has revealed that the bladder tumours are 
the commonest lesions seen in cystoscopic bladder biopsies and TCC makes the predominant tumour type. Besides, other investigations, early diagnosis on cystoscopic biopsies prevents the bladder carcinoma.

\section{REFERENCES}

1. Huben RP, Mounzer AM, Murphy GP, Tumour grade and stage as prognostic variables in upper tract urothelial tumours. Cancer. 1988; 62: 20162020.

2. Landis SH, Murray T, Bolden S, Wingo PA. Cancer Statistics. Cancer J. Clin. 1999; 9: 08-31.

3. Murphy DM, Zincke H, Furlow WL, Management of high-grade transitional cell cancer of the upper urinary tract. J Urol. 1981;125: 25-29.

4. Scher HI, Shipley WU and Herr HW. Cancer of the bladder. In Cancer principles and practice of oncology, VT. De-vita (et), $5^{\text {th }}$ Edition, Lippincott Raven. Philadelphia, p1300; 1997.

5. El-Bolkainy MN, Mokhtar MN, Ghoneim, MA and Hussein $\mathrm{MH}$. The impact of schistosomiasis on the pathology of bladder carcinoma. Cancer. 1981; 48: 2643-2645.

6. Landis $\mathrm{SH}$. Cancer statistics. CA Cancer J Clin. 1998;48:06-09.

7. Khan AN, Macdonalds S, Krishna LR. Transitional cell carcinoma. Available at: www.emedicine.com.
8. Nakao M, Nakagawa S, Toyoda K, Nukui M, Takada $\mathrm{H}$, Ebisul K, Watanabe $\mathrm{H}$. Clinico statistical study on bladder tumor. Nip Hin Gak Zas. 1989; 80:1037-1044.

9. Goonewardena SAS, De Silva WAS, De Silva MVC. Bladder cancer in Sri Lanka experience from a tertiary referral center. Int J Urol. 2004; 11: 969-972.

10. Vainrib M, Zelokovsky E, Erlich N, Eidelberg I, Kaneti $\mathrm{J}$ and Leibovitch I. Epidemiology of transitional cell carcinoma among Israeli Arabs. Harefuah. 2006; 145: 18-21.

11. Roohullah, Nusrat J, Hamdani Srh, Burdy GM, Khurshid A. Cancer Urinary Bladder, a 5-Year Experience at Cenar, Quetta. J Ayub Med Coll. 2001; 13:14-16.

12. Leader RA, Dunnick NR. Transitional cell carcinoma of the calicies and ureter. AJR. 1990; 155: 713-722.

13. Ahmed Z, Muzaffer S, Khan M, Kayani N, Pervez $S$, Husseini AS et al. Transitional cell carcinomas of the urinary bladder. A histopathological study. JPMA. 2002; 52:396-408.

14. Wender el, Goldsmith R. The epidemiology of bladder cancer a second look. Cancer. 1977; 40: 1246-1268.

AUTHOR AFFILIATION:
Dr. Syed Mehmood Hasan
Department of Pathology
Dow University of Health Sciences
Karachi - Pakistan.
Dr. Fauzia Imtiaz (Corresponding Author)
Department of Biochemistry
Dow University of Health Sciences
Karachi - Pakistan.
Email: fauziaku@yahoo.com
Dr. Syed Muhammad Hasan
Department of Medicine
Jinnah Postgraduate Medical Centre
Karachi - Pakistan.

